\title{
BANKING RISKS: ENHANCING REQUIREMENTS CONCERNING RISK MANAGEMENT AND INFORMATION DISCLOSURE
}

\begin{abstract}
The article deals with the nature,basic principles and objectives of the bank risk management system under modern conditions and the requirements of regulators to the transparency of its activities are considered. The authors developed a scheme of risk management and justified basic disclosure of banking risks in the context of introduction of the International Financial Reporting Standards.
\end{abstract}

Keywords: risk, risk management, information disclosure, transparency and corporate governance.

\section{Problem definition}

"Transparency is the foundation of a reliable and effective corporate governance ", is stated in the key postulates of Principles for enhancing corporate governance of the Basel Committee on Banking Supervision from 2010 [ 1]. In a such way during the overcoming of the global financial crisis consequences supranational regulator outlined the role of transparency in the growth of requirements to banking activities. Moreover, the key area to minimize the risk of financial intermediaries in the opinion of the Committee is an extensive information disclosure in accordance with established principles of International Financial Reporting Standards (hereinafter - IFRS) of the International Accounting Standards Board, which was amended in the part of the accounting and evaluation of financial instruments. In 2012 the Enhanced Disclosure Task Force Financial Stability Board published the report "Improving the quality of risk information disclosed by banks ", which emphasized that the existing disclosure requirements of banks are quite numerous and sometimes overlapping that impairs the perception of the financial statements [2]. As a result, inadequate risk assessments and provoking of regular crisis in the financial markets are possible.

While outlining the post-crisis global regulatory initiatives in formation of the requirements for the disclosure of the activities of financial institutions, including banks, it should be noted that they are aimed at the improving their risk management systems. National banking practice remains interested in the process of risk-based banking supervision at the macro level, improving risk management and disclosure of risks of banks at the micro level. It should be noted that the transition of the banking system of Ukraine to IFRS started in 1998 ended with the amendments to the Law of Ukraine on the obligatory drafting and presentation of the financial statements of banks according to these standards. Therefore, the providing of proper disclosure about the level of banking operation risks is the basis of banking risk management and the issues outlined above are relevant.

\section{Literature overview}

The issues of risk management and disclosure in the financial statements are highlighted in international documents of such prestigious organizations as the Basel Committee on Banking Supervision, the International Accounting Standards Board, and in the writings of scholars N. Glebova, M. Polozhevets, L. Prymostka O. Ustenko etc. At the same time in conditions of reforming of the banking risk management methodology and IFRS application the issue of transparency in risk disclosures remains not well-studied.

\section{Aim Setting}

Given the significant scope and wideness of the issues under consideration the article raises a number of more specific objectives, namely:

- describe the nature, fundamental principles and objectives of the implementation of the bank risk management in the current environment; 
- develop a scheme of bank risk management;

- justify the main trends and requirements as for the disclosure of the banking risks.

\section{Results of research}

Today in Ukraine the risk has quite weighty impact on almost all of the processes taking place in the political and economic spheres, as well as on banking system. However, despite the rapid spread of risk management practices in banks, there is no single definition of "bank risk" so far. Most often the likelihood of events that adversely affect the income or capital of a commercial bank is understood under this concept.

Risk Management - a system of principles and methods for prediction, prevention, evaluation and neutralization the negative impact of threats and dangers affecting the bank [3].

The basic principles of the implementation of risk management are [4]:

- The principle of scale (maximization);

- The principle of minimization;

- The principle of adequate response;

- The principle of rational acceptance.

The task of risk management are as follows:

- Identifying the most vulnerable and weak spots in the banking activity;

- Systematic comprehensive diagnostics of likelihood of adverse events;

- Choice of alternative variants of management decisions to provide optimal balance between risk and profitability of financial transactions;

- Minimization of losses upon the occurrence of adverse events.

Risk management of banking consists of a series of successive stages which are shown in Figure 1. Let us consider in more details the elements of the proposed scheme of risk management of a commercial bank.

The first stage - analysis of factors and conditions that affect the likelihood of risk. A large number of factors affect the activities of any bank directly or indirectly. The whole complex of them can be divided into two types: internal environment factors and environmental factors. The action of the first group is conditioned by specific activities of banking institutions: policy, strategy, tactics, and personnel and their qualifications, organizational structure, and so on. The influence of environmental factors is realized through regulation (standards, procedures, guidelines, standards of accounting for the regulation of risk) and through interaction with the external environment (customers, competitors, partners, etc.).

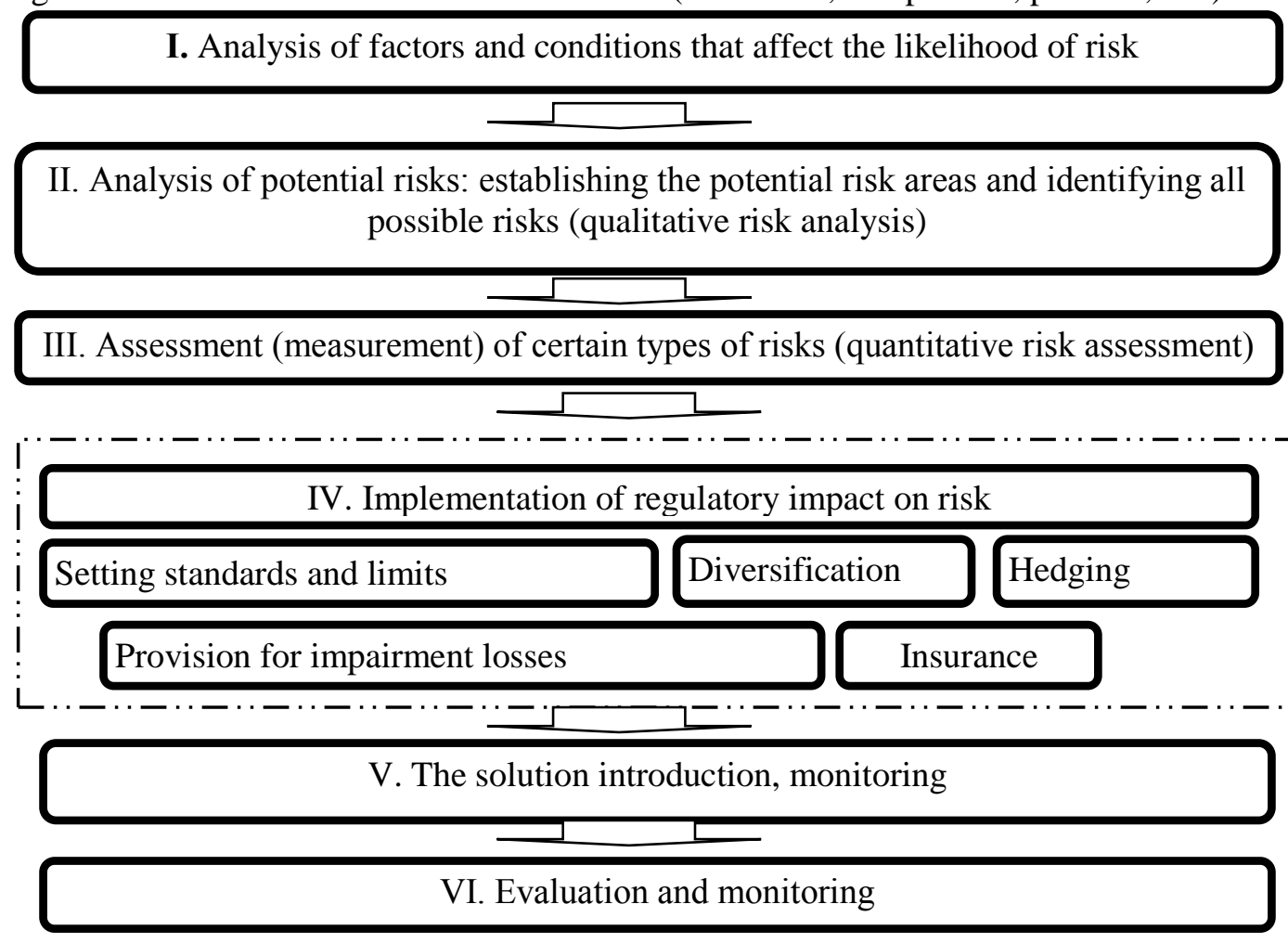


Figure 1. Scheme of bank risk management

An the second stage the parameters of all possible risks are set, the reasons of their occurrence and possible consequences are analyzed. It should be noted that at present there are many different options and approaches to the classification of banking risks. Each author or a group of authors offer their own classification criteria when choosing the sphere of the functioning of risks. In general, banking risks can be divided into three main groups: financial, functional and other external ones [5].

Financial risks arise as a result of bank lending, deposit, investment. They are determined by the probability of losing money and are associated with unforeseen changes in volumes, profitability, value and composition of assets and liabilities.

Functional risks arise by the creation of any bank product or service because of inability to control the financial and economic activities timely and fully, to collect and analyze relevant information.

Other external risks include risks that are beyond the control of the bank's activities (political situation, economic situation, force majeure ).

However, financial risks constitute the particular interest for this research. Let us consider the main types of financial risks that are specific for banks.

Banking credit risk - a measure (degree) of uncertainty concerning the occurrence of adverse events when carrying financial transactions, the essence of which is that the bank's counterpart fails to fulfill his obligations according to the agreement and will not be able to take advantage of ensuring the return of borrowed funds.

Deposit risk of commercial banks - a measure (degree) of uncertainty about the possibility of transfer or settlement of current account to another bank or early withdrawal of deposit.

Currency risk of the commercial bank - a bank will suffer losses due to fluctuations in exchange rates and the prices of precious metals.

Interest rate risk of commercial banks - a measure (degree) of uncertainty about the possibility of suffering losses by a bank due to adverse changes in interest rates.

The investment risk of the bank - a measure (degree) of uncertainty about the possibility of depreciation of securities purchased by the bank.

The liquidity risk of commercial banks - a measure (degree) of uncertainty regarding the ability of the bank to ensure timely fulfillment of obligations to clients by converting assets into cash.

The risk of insolvency (bankruptcy) - a measure (degree) of uncertainty as to the ability of a bank to meet its obligations.

The third stage - Evaluation of certain types of risk. Depending on the type of banking transaction a quantitative evaluation of possible losses is performed, and the probability of an unwanted event which results in the loss is determined. For this purpose, different techniques may be used depending on the specific type of risk. In particular, the calculation of the sensitivity of the portfolio value to market factors : alpha, beta analysis, the duration analysis , the calculation of credit risk - as the correlation between different borrowers: liquidity risk and funding - calculation of gap liquidity, operational risk - the organization of the system of monitoring of operations linked to the laundering ( legalization of dirty money) and so on.

The next one, the fourth stage - implementation of regulatory impact on risk. At this stage the search of ways of timely and quality protection against unacceptable risk and the development of specific mechanisms for their implementation is performed. Planning of activities for both prevention and for the case of risk realization.

Let us consider in more detail the most universal methods of management of banking risks, namely:

- Setting standards and limits - is realized by placing restrictions on the amount of financial transactions with the following control of the implementation of decisions made. Usually this method is used to avoid concentrations of credit and market risk and liquidity support to the banking system at a certain level ; 
- Diversification of risk - is based on risk division and can take the form of diversification of financial activities, diversification of currency portfolio, diversification of deposit portfolio, diversification of the program of real investment, etc.;

- Provision for impairment losses - provides risk coverage for the bank's own funds that are reserved (reserve for credit transactions, security transactions, receivables );

- Hedging - is based on the use of financial instruments to reduce the risk associated with the negative impact of market factors on the price of another one related to the first tool. Designated tool is used to reduce the risk of losses associated with the change in market factors (price of financial instruments, exchange rates, interest rates) by taking certain measures;

- Insurance - the transfer of risk by the contract according to which the insurance company is the debtor.

In practice, to reduce the credit risk of commercial banks insurance, limits, diversification and provisions are used. The most effective method to reduce risk is to diversify deposit contributors and limits, that is setting the critical amount of deposit. The main method of the measurement of interest rate risk of the bank is to analyze gap (difference between the size of sensitive to changes interest rates of assets and liabilities that should be revaluated or liquidated by a certain date ). The main methods of reducing the interest rate risk of commercial banks are the gap management, immunization of portfolio, insurance, which provides a complete transfer of corresponding risk to insurance companies and others.

Having reviewed the key aspects of building of the modern risk management systems of banks, let us focus on other integral components of corporate governance such as information disclosure and transparency of banking.

Basel Committee on Banking Supervision determined "transparency " as " the disclosure of accurate and timely information allowing users to assess the financial position and results achieved by the bank, its operations and associated risks accurately".

It should be stressed that the demonstration of the bank 's ability to manage risks and control them effectively is a sign of a well-functioning capital market activity, and statements that corresponds to IFRS (generally recognized accounting and reporting standard system) is a way of such a demonstration.

Widely recognized document " International Convergence of Capital Measurement and Capital Standards: New Approaches" (Basel II) [ 6] "The international regulatory framework for banks" (Basel III ) «International regulatory framework for banks» [ 7] of Basel Committee on Banking Supervision and Requirements IFRS 7 "Financial Instruments : Disclosure " [8 ], share some of the provisions in the sensitivity analysis and in describing risks and risk management policy. Along with other documents (Table 1), the ones mentioned above are aimed at unification of the requirements for comparability and understandability of information about the risks of banks' reporting.

Table 1

Key international documents containing the requirements for disclosure of banks' risk management

\begin{tabular}{|c|c|c|}
\hline Document & Organization & Released \\
\hline $\begin{array}{l}\text { Basel III (part of strengthening of banks' } \\
\text { transparency and disclosures) }\end{array}$ & $\begin{array}{l}\text { Basel Committee on Banking } \\
\text { Supervision }\end{array}$ & 2011 \\
\hline $\begin{array}{l}\text { Principles for enhancing corporate governance } \\
\text { (Disclosure and transparency) }\end{array}$ & $\begin{array}{l}\text { Basel Committee on Banking } \\
\text { Supervision }\end{array}$ & 2010 \\
\hline $\begin{array}{l}\text { Compensation Principles and Standards } \\
\text { Assessment Methodology }\end{array}$ & $\begin{array}{l}\text { Basel Committee on Banking } \\
\text { Supervision }\end{array}$ & 2010 \\
\hline IFRS 7 «Financial instrument : disclosure» & $\begin{array}{l}\text { International accounting standards } \\
\text { board }\end{array}$ & 2007 \\
\hline Basel II & $\begin{array}{l}\text { Basel Committee on Banking } \\
\text { Supervision }\end{array}$ & 2004 \\
\hline OECD Principles of Corporate Governance & $\begin{array}{l}\text { Organization for Economic } \\
\text { Co-operation } \\
\text { and Development }\end{array}$ & 2004 \\
\hline Best Practices for Credit Risk Disclosure & $\begin{array}{l}\text { Basel Committee on Banking } \\
\text { Supervision }\end{array}$ & 2000 \\
\hline
\end{tabular}




\begin{tabular}{|l|l|l|}
\hline $\begin{array}{l}\text { Public disclosure of trading and derivatives } \\
\text { activities of banks and securities firms }\end{array}$ & $\begin{array}{l}\text { Basel Committee on Banking } \\
\text { Supervision }\end{array}$ & 1999 \\
\hline $\begin{array}{l}\text { Enhancing Bank Transparency: Public disclosure } \\
\text { and supervisory information that promote safety } \\
\text { and soundness in banking systems }\end{array}$ & $\begin{array}{l}\text { Basel Committee on Banking } \\
\text { Supervision }\end{array}$ & 1998 \\
\hline
\end{tabular}

Thus, according to the Principles of enhancing corporate governance the bank must disclose key aspects of tolerance / appetite for risk (without violating confidentiality required) with the description of the process of risk determination and of involvement of managers in these processes. If there are transactions with complex and opaque structures, the bank must disclose adequate information about the purpose, strategy, structure, risks and control of such activities [1].

Basel III contains requirements to increase of capital coverage of counterparty credit risks, in operations with financial derivatives in particular, with repurchase agreements, transactions with asset securitization and other structured instruments. Unlike the traditional approach to understanding the credit risk for the loan, CCR creates a bilateral risk of loss : the market value of the transaction can be positive or negative for each of the parties of this agreement, and the market value is an uncertain measure, it can change over time as the basic market factors change.

It should be noted that Pillar 2 (control) concentrates on strengthening of supervision on the calculation of capital, risk management, corporate governance, risk taking, risk aggregation, the introduction of stress tests, and the component of Pillar 3 ( disclosure ) - the increase of market discipline and information disclosure of certain types of risks.

Within Pillar 3 of Basel II the general requirements to the disclosure according to the types of banking risks (discussed in the previous scheme of their management) are established (Table 2).

Table 2

Basel II disclosure of the banking risks

\begin{tabular}{|c|c|}
\hline Risk & Disclosure \\
\hline 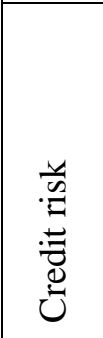 & $\begin{array}{l}\text { Total gross exposure of bank credit risk, and the average gross risk during the period, divided } \\
\text { into major subtypes of risk; } \\
\text { - Geographical distribution of credit risk; } \\
\text { - The distribution of credit risk by industry and type of counterparty (on a consolidated basis); } \\
\text { - Concentration risk on large borrowers and lenders (depositors); } \\
\text { - Breakdown by contractual residual maturity of the total loan portfolio and its components; } \\
\text { - Past due, restructured loans and prolonged, as well as provisions for losses on them }\end{array}$ \\
\hline 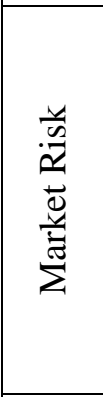 & $\begin{array}{l}\text { - The structure of the market risk, including disclosure } \\
\text { - The approach ( capital requirements to interest rate coverage risk, equity risk, foreign currency } \\
\text { risk, commodity risk) and present quantitative estimates VaR; } \\
\text { - The carrying and fair value of securities portfolios ; } \\
\text { - Cumulative realized and unrealized gains (losses ) for the various portfolios of securities; } \\
\text { - Assessment of growth ( decrease) in income or economic value of equity in different scenarios } \\
\text { shocks in interest rates; } \\
\text { - The structure of claims outstanding the securitized bank }\end{array}$ \\
\hline 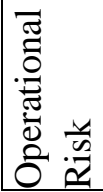 & $\begin{array}{l}\text { - Approaches to evaluation of capital adequacy under operational risk, including review of existing } \\
\text { internal and external factors and their quantitative assessment }\end{array}$ \\
\hline
\end{tabular}

Despite the chosen course on the convergence of international disclosure requirements at the global level, there are some differences between the regulatory documents of the Basel Committee on Banking Supervision and the International Accounting Standards Board, particularly in the part of the identification of certain types of risks, rules of their evaluation and reflection.

According to IFRS the risks of the banks for which disclosure is required include credit, market ( currency, interest rate, other market risk ) and liquidity risk, while the Basel Committee on Banking Supervision operates the following types of risks: credit, operational risk, market (interest rate, equity 
securities, currency, commodity ) risk. These institutions have different approaches to determination of loss, the occurrence of default probability, calculation of provisioning [9 ].

However, it should be noted that in general IFRS 7 has more detailed requirements to the disclosure of qualitative and quantitative information about the risks of banks ( Fig. 2).

This information about the risks associated with financial instruments is disclosed in the financial statements or, or any other statement, such as the management commentary to the annual report or a separate risk report.

IFRS 7 sets higher requirements for quantitative and qualitative analysis of currency risk, interest rate risk, liquidity risk and other price risks. Disclosure of qualitative information includes a description of objectives, policies, management and control of such risks. Quantitative disclosure provides information about the level of risk. Having this information in the financial statements gives users an overview of the use of financial instruments by the entity and of the risk exposure arising as a result of this.

The standard also requires a summary of quantitative information about the susceptibility of enterprise to each type of risk at the reporting date. This information should be presented "through the eyes of management", i.e. on the basis of internal reports that are submitted to managers.

It should be emphasized that the future of risk management and information disclosure lies in the plane of convergence of the studied international requirements and the development of a unified list of disclosures about the various aspects of control and risk characteristics from the position of interested users. 
Disclosure requirements of the banking risks (IFRS 7)

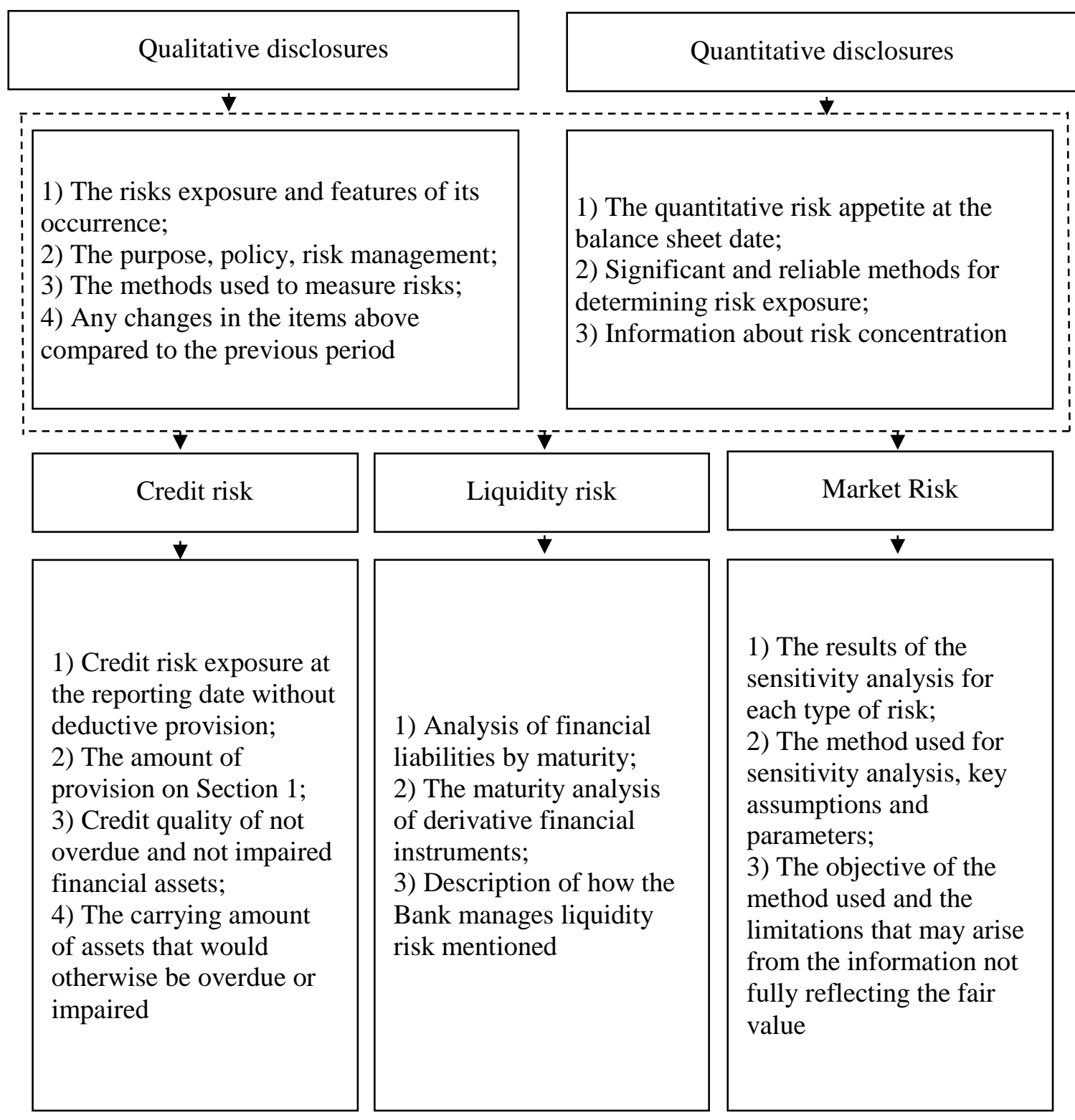

Figure 2. Scheme of bank's risks disclosures in the financial statements (IFRS 7)

\section{Conclusions}

Understanding risk management as a system of principles and methods of prediction, prevention, evaluation and neutralization of the negative impact of threats and dangers on the bank, the scheme that takes into account both the stages of analysis of risk factors (including quantitative ) and modern methods of risk leveling was built. Moreover, in response to international efforts to overcome the global financial crisis the need for systematization and detailed analysis of the regulations in this sphere increases. The analysis suggests that the disclosure of information about the different types of bank's risks and their characteristics is the basis for the creation of the bank risk management systems in accordance to generally accepted examples of international practice as Basel II, Basel III and other documents of the Basel Committee on Banking supervision, IFRS. The submission of detailed information (quantitative and qualitative aspects) about specific types of banking risks, methods of identification and measurement, sensitivity analysis along with general information about the structure and principles of risk management system are the main directions of the bank transparency increase. 


\section{Future Research Prospects}

Within the outlined issues the question of the implementation of international practice of bank risk management into the national banking system requires further consideration. An important aspect of this introduction is the disclosure of such risks in the financial statements of banks, which must necessarily take into account the requirements of IFRS 7, that contain more sophisticated approaches to the formation of accurate, clear, relevant and comparable information in terms of accounting and risk reflection in their financial statements in comparison to previous national standards.

1. Principles for enhancing corporate governance - final document. Basel Committee on Banking Supervision. - 2010. - Access: http://www.bis.org/publ/bcbs176.htm. 2. Раскрытие информации о рисках в финансовой отчетности: пути к совершенству. - КPMG, 2012. - Выпуск 14. - Режим docmyna: $\quad$ www.kpmg.com/RU/ru/.../ifrs.../IntheHeadlines2012_14_RUS.pdf. 3. Положевещь M. Управління ризиками підприємства та шляхи їх нейтралізації / М. Положевеиь // Актуальні проблеми економіки, обліку та менеджменту. - 2012. - № 8. - С. 22-24. 4. Устенко О. Л. Теория экономического риска : монографія / О. Л. Устенко. - К. : МАУП, 1997. - 164 с. 5. Примостка Л. О. Фінансовий менеджмент у банку: Підручник. - 2-ге вид., доп. і перероб. - К.: КНЕУ, 2004. - 468 с. 6. Basel II : International Convergence of Capital Measurement and Capital Standards: A Revised Framework. - 2006. - Access: http://www.bis.org/publ/bcbs128.htm. 7. Basel III : International regulatory framework for banks. - 2011. - Access: http://www.bis.org/bcbs/basel3.htm. 8. IFRS 7 -Financial Instruments: Disclosures. - Access: www.ifrs.org. 9. Глєбова Н. В. Розкриття інформаиї̈ у фінансовій звітності банківських установ відповідно до МСФЗ та Базельського комітету / Н. В. Глєбова // Бізнес-інформ. - 2012. - № 11. - С. 236-240. 